\title{
Mumps Vaccination in the Czech Republic
}

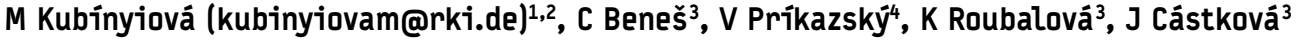 \\ 1. Robert Koch Institute, Berlin, Germany \\ 2. European Training Programme for Intervention Epidemiology (EPIET), European Centre for Disease Prevention and Control \\ (ECDC), Stockholm, Sweden \\ 3. Státní Zdravotní Ústav (National Institute of Public Health), Prague, Czech Republic \\ 4. European Centre for Disease Prevention and Control (ECDC), Stockholm, Sweden
}

To the Editor: I would like to comment on the article "Increased mumps incidence in the Netherlands: Review on the possible role of vaccine strain and genotype' by Kaaijk et al., published in the last issue of Eurosurveillance [1]. Table 1 of the article describes the available mumps vaccine strains. I found the information regarding the mumps vaccine used in the Czech Republic to be inaccurate* and would like to take this opportunity to present a more complete picture of Czech mumps vaccine history.

In former Czechoslovakia, compulsory routine two-dose vaccination against mumps was implemented in 1987, with the first dose given at the age of 15 months and the second dose 6-10 months after first [2].

The monovalent vaccine 'Pavivac' (officially registered in the newly formed Czech Republic in 1993), the divalent vaccine 'Mopavac' against mumps and measles (registered in 1995) and the trivalent MMR vaccine called 'Trivivac' (registered in 1995) were in use at different times. All three vaccines are produced by SEVAPHARMA Inc. Company, all are derived from the live attenuated parotitis virus strain Jeryl Lynn/genotype A [3].

In 1999 and 2007, Priorix and Priorix-Tetra vaccines, respectively, were registered in the Czech Republic. These vaccines contain live attenuated parotitis virus RIT4385, derived from the Jeryl-Lynn strain [4].

Compulsory routine vaccination in the Czech Republic is prescribed by Czech law, covered by the Czech Government and administered by a general practitioner. All children and adults who legally reside in the territory of the Czech Republic and have mandatory health insurance, have the right to be vaccinated.

Data on individual mumps cases in the Czech Republic have been reported since 1955 . The case definition for mumps follows EU decision No 2119/98/EC [5] and was used even before implementation of this decision. Reported cases are laboratoryconfirmed cases and cases that meet the clinical case definition with an epidemiological link to a laboratory-confirmed case.

Before the implementation of routine childhood mumps vaccination in the Czech Republic, the occurrence of parotitis was cyclic in intervals of three to five years, with an average incidence of 497 per 100,000 inhabitants. Since 1987, the incidence of parotitis has decreased rapidly, and only three epidemics of mumps have been noticed, mostly involving the same age cohort born between 1981 and 1988.

In 1995-1996, 11,680 cases of mumps were reported, most of them among children between the age of 10 and 14 years living in the Northern Moravian region of the Czech Republic. The same age cohort (15-19 years-old) was affected again in 2002/2003 in the South Bohemian region. A third epidemic occurred in 2005/2006, again among 15-19 year-olds, as described thoroughly by Boxall et al. [2].] In partially vaccinated populations, mumps epidemics tend to occur every three to five years. The age group that was most affected was too old to have received the childhood vaccination, but their exposure to wild mumps virus was reduced by the herd effect of the immunisation programme.

The level of immunity in the population that is required to reach mumps elimination is estimated to be $95 \%$ [7]. The occurrence of mumps epidemics in the Czech Republic shows an inter-epidemic period pattern with high vaccination coverage (>95\%). Due to the accumulation of susceptible individuals, outbreaks can be expected 10 to 20 years following the introduction of a routine immunisation programme [7]. The percentage of the Czech population susceptible to mumps was assessed as being $12 \%$, based on a serosurvey done in 2001 [10].

The latest mumps epidemic in the Czech Republic in 2005/2006 was caused by genotype G (G1 and G5).

*Note: Table 1 in the said article by Kaaijk et al. has been corrected on 2 July 2008 on request of the authors.

\section{References}

1. Kaaijk P, van der Zeijst BA, Boog MC, Hoitink CW. Increased mumps incidence in the Netherlands: Review on the possible role of vaccine strain and genotype . Euro Surveill. 2008;13(26):pii=18914. Available from: http://www. eurosurveillance.org/ViewArticle.aspx?ArticleId=18914

2. Boxall N, Kubínyiová M, Príkazský V, Beneš C, ČástkováCástková J. An increase in the number of mumps cases in the Czech Republic, 2005-2006. Euro Surveill. 2008;13(16):pij=18842. Available from: http://www.eurosurveillance. org/ViewArticle.aspx?ArticleId=18842

3. SEVAPHARMA Inc. Pharmacokinetic data. [In Czech]. Available from: http:// www.sevapharma.cz/vaccines_v_en.php

4. GlaxoSmithKline. Data on vaccines available in the Czech Republic. [In Czech]. Available from: http://www.gsk.cz/ 
5. Official Journal of the European Communities: Commission Decision of 22 December 1999 on the communicable diseases to be progressively covered by the Community network under Decision No 2119/98/EC of the European Parliament and of the Council. 3 February 2000. Available from: http://eurlex.europa.eu/pri/en/oj/dat/2000/l_028/l_02820000203en00500053.pdf

6. Galazka AM, Robertson SE, Kraigher A. Mumps and mumps vaccine: a global review. Bull World Health Organ. 1999;77(1):3-14.

7. Tischer A, Gerike E. Immune response after primary and re-vaccination with different combined vaccines against measles, mumps, rubella. Vaccine. 2000;18(14):1382-92.

8. Mrázová M, Šmelhausová M, Šestáková Z. Sérologický přehled ČR v roce 2001 - př́ušnice. Zprávy CEM. 2003;12(př́loha 1):44-8. [In Czech].

This article was published on 3 July 2008.

Citation style for this article: Kubínyiová M, Beneš C, Príkazský V, Roubalová K, Cástková J. Mumps Vaccination in the Czech Republic. Euro Surveill. 2008;13(27):pii=18920. Available online: http://www.eurosurveillance.org/ViewArticle.aspx?ArticleId=18920 